\title{
New Fabrication Techniques for Micro-Tubular Hollow Fiber Solid Oxide Fuel Cells
}

\author{
N. Droushiotis*, A. Hankin and G. H. Kelsall \\ Department of Chemical Engineering, Imperial College London, South Kensington, \\ London SW7 2AZ, UK \\ (* Now at: Shell )
}

\begin{abstract}
A novel combination of phase inversion and electrophoretic deposition was used in the fabrication of anode supported micro tubular (hollow fiber) solid oxide fuel cells (MT-HF-SOFCs). The phase inversion process was used to produce ca. $240 \mu \mathrm{m}$ thick, highly porous $60 \mathrm{wt} . \% \mathrm{NiO}-40 \mathrm{wt} . \%$ yttria-stabilised zirconia (YSZ) hollow fiber anode precursors. The electrophoretic deposition process was then used to apply ca. $40 \mu \mathrm{m}$ thick, particulate YSZ electrolyte layers onto the unsintered NiO-YSZ HFs from an ethanol suspension at an applied electric field of ca. $0.22 \mathrm{kV} \mathrm{cm}^{-1}$. The YSZ-coated NiO-YSZ HFs were sintered at $1500{ }^{\circ} \mathrm{C}$ for twelve hours. Dispersions of YSZ-LSM particles were then painted on top of the electrolyte layer, as 'graded' YSZ-LSM porous cathode precursors that were sintered at $1200{ }^{\circ} \mathrm{C}$ for three hours. The fabrication process was completed by winding silver wire current collectors spirally round the cathodes and through the lumen of the fibers to enable current collection from the anodes. Single MT-HF-SOFCs delivered peak power densities of 0.20 , 0.18 and $0.14 \mathrm{~W} \mathrm{~cm}^{-2}$ at 800,750 and $700{ }^{\circ} \mathrm{C}$, respectively, with flow rates of $15 \mathrm{~cm}^{3} \min ^{-1} \mathrm{H}_{2}\left(97 \% \mathrm{H}_{2}-3 \% \mathrm{H}_{2} \mathrm{O}\right)$ and $30 \mathrm{~cm}^{3} \mathrm{~min}^{-1}$ of air.
\end{abstract}

\section{Introduction}

Micro-tubular (MT) - solid oxide fuel cells (SOFCs), which typically have sub-millimeter inner diameters and $>1 \mathrm{~mm}$ outer diameters, are being developed for efficient conversion of chemical to electrical energy. Their potentially high volumetric power densities (PDs) and tolerance to rapid thermal cycling make them attractive for use as portable power sources.

In addition to dimensional considerations, great emphasis is being placed on achieving appropriate microstructures of anodes, electrolytes and cathodes. Anodes and cathodes must have porous microstructures to facilitate gas entry into the electrodes, but must also have high electronic conductivities. The contacts between each electrode and electrolyte layer must have high surface areas to increase densities of triple phase boundary (TBPs) lengths, where electrochemical reactions occur. Finally, the electrolyte layer between the electrodes must be non-porous in order to minimize gas leakage between the electrodes, have a high ionic (and low electronic) conductivity and be thin in 
order to minimize ohmic potential losses. Many fabrication techniques are being devised to meet these requirements, while decreasing fabrication complexity and costs.

A novel MT-SOFC fabrication technique is being investigated, based on anode hollow fiber (HFs) precursors, produced by phase inversion (PI) (1), that are co-sintered with the electrolyte layer, applied by electrophoretic deposition (EPD). The PI technique, followed by sintering of the metal oxide precursors, produces HFs with controlled microstructures, eminently suitable for making MT-SOFCs. Compared to ram extrusion, PI may decrease costs, enable better control of structures of extruded layers and impose minimal restrictions on HF lengths and diameters. The extrusion of both single layer and double layer HFs using PI, for use in SOFC technology, has been reported previously $(1,2,3,4,5,6,7,8)$.

Likewise, the use of electrophoretic deposition in the co-fabrication of the anode and electrolyte layers in MT-SOFCs has been explored $(9,10)$ and is receiving growing attention for its application in fuel cell fabrication in general (11). Amongst its many advantages, it enables good control over deposition rates and resultant deposit densities, is applicable to both planar and tubular structures and is not costly (9). During electrophoresis, charged ceramic particles, suspended in solution, migrate under an applied electric field towards the surface of opposite charge and subsequently deposit on it due to coagulation, without the involvement of electrochemical reactions (12).

However, the sequential combination of the phase inversion and electrophoretic deposition techniques in the fabrication of the anode | electrolyte structure for use in MTHF-SOFC development has never before been attempted.

This report details the development of the strategy, which was used to achieve successful application of electrolyte material onto anode hollow fiber precursors by electrophoretic deposition, leading to competitive MT-HF-SOFC performance.

\section{Experimental}

\section{Fabrication of HF Precursors for Anode-Supported MT-SOFC by Phase Inversion}

The phase inversion process, used to produce single layer HF precursors, principally involves the preparation and the spinning of the oxide suspension into a coagulation bath in order to produce solid HFs.

The spinning suspension was prepared according to the procedure in (7), by mixing the $\mathrm{NiO}\left(0.6 \mu \mathrm{m}\right.$ mean particle diameter, Nextech Materials Ltd., USA) and YSZ $\left(\mathrm{ZrO}_{2}+\right.$ $8 \mathrm{~mol} \%$ yttria, $0.3 \mu \mathrm{m}$ mean particle diameter, Nextech Materials Ltd., USA) powders in N-methyl-2-pyrrolidone solvent (HPLC grade, Sigma Aldrich) with polyethersulfone polymer binder (Radel A300, Ameco Performance, USA) and Arlacel P135 dispersant (Uniqema, Spain).

This spinning suspension was pressurised through a circular cavity (inner diameter of $1.6 \mathrm{~mm}$ and outer diameter of $3.0 \mathrm{~mm}$ ) in a stainless steel spinneret, thus giving rise to the hollow tubular shape. At the same time, an internal coagulant (deionized $\mathrm{H}_{2} \mathrm{O}$, 
purified in Elga Elgastat Prima, UK) was pumped through the innermost cavity in the spinneret. The spinning entities descended into a tank of non-deionized $\mathrm{H}_{2} \mathrm{O}$. The solidification of the fiber occurred due to the solvent exchange with $\mathrm{H}_{2} \mathrm{O}$, in which $\mathrm{NiO}$ and YSZ are insoluble, on both the outer and inner faces of the fiber. The difference in viscosities between $\mathrm{H}_{2} \mathrm{O}$ and de-ionised $\mathrm{H}_{2} \mathrm{O}$ generated a difference in microstructures across the thickness of the fiber. The fiber precursors were composed of $60 \mathrm{wt} . \% \mathrm{NiO}$ and $40 \%$ wt. YSZ.

\section{Application of the Electrolyte Layer by Electrophoretic Deposition}

For all electrophoretic deposition experiments, the electrolyte comprised YSZ particles suspended in ethanol $(96 \% \mathrm{v} / \mathrm{v}, \mathrm{VWR})$, to which $2.5 \mathrm{~g} \mathrm{dm}^{-3}$ of poly(vinyl butyral-co-vinyl alcohol-co-vinyl acetate) (Sigma Aldrich, UK) polymer binder were added to enhance the strength and adhesion of the deposit and prevent cracking. The total concentration of YSZ $\left(8 \mathrm{~mol} \% \mathrm{Y}_{2} \mathrm{O}_{3}\right.$ stabilized $\left.\mathrm{ZrO}_{2}\right)$ in the suspension amounted to $10 \mathrm{~g} \mathrm{dm}^{-3}$, of which $70 \%$ was added as 5-10 nm diameter particles (Fuelcellmaterials, USA) and the remaining $30 \%$ as $0.4 \mu \mathrm{m}$ diameter particles (PI-KEM Ltd., UK). Prior to suspension in ethanol, the YSZ particles were washed several times in de-ionised water in order to remove $\mathrm{Cl}^{-}$ions and other impurities. The suspension was ultrasonicated with a high intensity ultrasonic probe (SM-15, Sonics \& Materials Inc., USA) for 5 minutes prior to the initiation of the deposition processes.

The use of acetyl acetone (pure, Sigma Aldrich) and acetone (96\% v/v, VWR) as solvents instead of ethanol was also investigated. However, it was generally found that the higher evaporation rates of acetyl acetone and acetone compared with ethanol during drying resulted in material detachment and formation of cracks in the electrolyte layer even before sintering.

Electrophoretic deposition of the YSZ electrolyte was examined on two types of HFs, both originating from the $60 \mathrm{wt} . \% \mathrm{NiO}$ and 40wt. \% YSZ precursors produced using the phase inversion technique.

Deposition of YSZ particles onto Pre-Reduced Fibers. Prior to the deposition of the YSZ electrolyte by EPD, the NiO-YSZ anode precursors were pre-reduced according to reaction 1 at $1200{ }^{\circ} \mathrm{C}$ in a $\mathrm{H}_{2}$ atmosphere for 2 hours.

$$
\mathrm{YSZ} / \mathrm{NiO}-\mathrm{YSZ}+\mathrm{H}_{2} \longrightarrow \mathrm{YSZ} / \mathrm{Ni}-\mathrm{YSZ}+\mathrm{H}_{2} \mathrm{O}
$$

For YSZ deposition, the Ni-YSZ fibers were polarised negatively in an electrochemical cell containing the dispersion of $\mathrm{YSZ}^{+}$particles. A cylindrical $\mathrm{Pt} / \mathrm{Ti}$ mesh, positioned at a $5 \mathrm{~mm}$ radius around the fiber, acted as the positive counter electrode. This arrangement is similar to that employed in (13). A cell potential of $10 \mathrm{~V}$ was applied (236 High voltage power supply, Keithley Instruments Inc., USA) between the Ni-YSZ fiber and the Pt/Ti mesh, resulting in an electric field of ca. $2 \times 10^{-2} \mathrm{kV} \mathrm{cm}^{-1}$, for 10 minutes. Subsequently, the deposits were dried at room temperature for 1 hour and sintered in air at $1400{ }^{\circ} \mathrm{C}$ for 4 hours.

Deposition of YSZ onto Non-Reduced Fibers. In order to deposit YSZ onto a nonconductive NiO-YSZ fiber, a copper wire was placed in its lumen to act as the cathode 
electrode. In the presence of an electric field, applied between the $\mathrm{Cu}$ wire and $\mathrm{Pt} / \mathrm{Ti}$ mesh electrode, the positively charged YSZ particles migrated towards the $\mathrm{Cu}$ cathode electrode, but deposited on the porous NiO-YSZ surface, which formed the physical barrier between the $\mathrm{YSZ}^{+}$particles and the wire. This process is depicted in a top-view schematic in Figure 1, which shows that the applied electric field penetrates the nonconductive, yet porous, structure of the NiO-YSZ fiber.

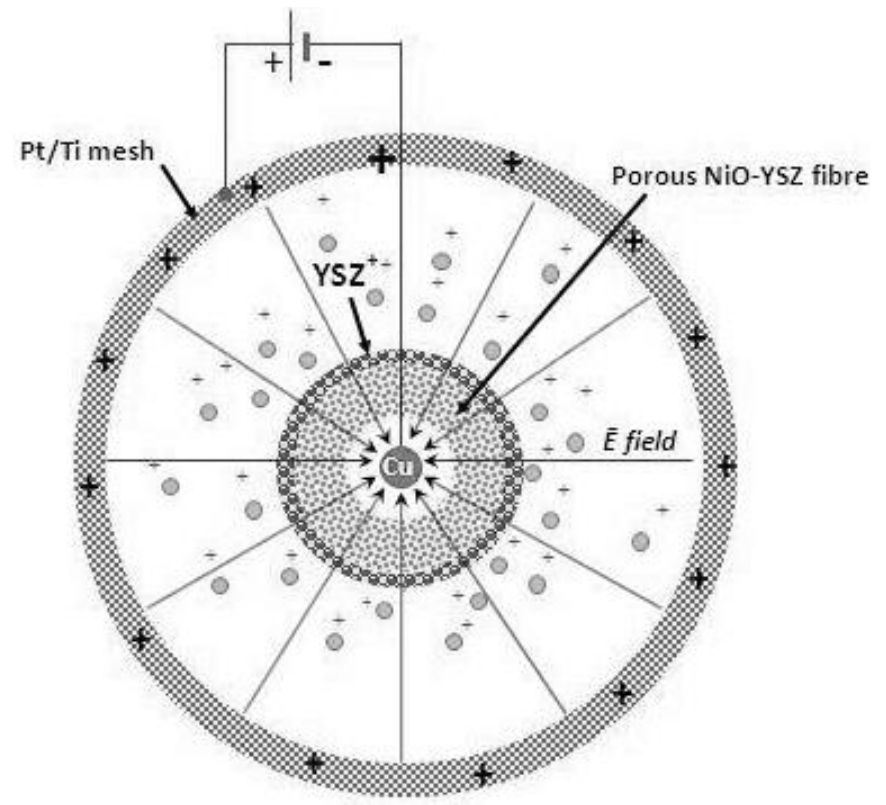

Figure 1: Top view of the electrophoretic deposition equipment: positively charged YSZ particles deposit onto the NiO-YSZ fiber under the influence of the electric field, applied between the copper wire in the lumen of the fiber and the Pt/Ti mesh counter electrode.

Two strategies were tested for the application of the electrolyte onto NiO-YSZ fibers that had not been subjected previously to heat treatment:

1. The first strategy involved the deposition of the YSZ electrolyte onto the HF in four separate applications. Following the application of each layer by EPD, the fiber was dried and sintered. The first, second, third and fourth coatings were deposited under applied cell voltages of 10,30, 60 and $110 \mathrm{~V}$, respectively, and were each applied over the period of 2 minutes. Increasingly high cell voltages were required to overcome the building resistance of the deposited electrolyte, the porosity of which decreased during sintering. Each sintering step was conducted for 2 hours in an $\mathrm{N}_{2}$ atmosphere and the sintering temperatures employed after the first, second, third and fourth coatings were $1250,1300,1350$ and $1400{ }^{\circ} \mathrm{C}$, respectively. This procedure was employed in order to determine whether gradual co-sintering of the anode and electrolyte resulted in compatible rates of thermal expansion of the two layers and thus improved the final profile between them.

2. The second strategy involved the application of the YSZ electrolyte onto the NiOYSZ fiber precursor in a single step at an applied voltage of $110 \mathrm{~V}$, corresponding to an electric field of ca. $0.22 \mathrm{kV} \mathrm{cm}^{-1}$, for 2.5 minutes. Subsequently, the samples were dried in a controlled mixed ethanol/air atmosphere for 30 minutes and sintered. Based on the 
sintering profile described in (4), the sintering temperature was increased initially from room temperature to $400{ }^{\circ} \mathrm{C}$ at a rate of $2{ }^{\circ} \mathrm{C} \mathrm{min}{ }^{-1}$ and held for 1 hour, then to $800{ }^{\circ} \mathrm{C}$ at a rate of $2{ }^{\circ} \mathrm{C} \mathrm{min}{ }^{-1}$ and held for 2 hours and finally to the target temperature of $1500{ }^{\circ} \mathrm{C}$ at a rate of $15^{\circ} \mathrm{C} \mathrm{min}{ }^{-1}$ which was maintained for 12 hours. The temperature was then decreased to room temperature at a rate of $5{ }^{\circ} \mathrm{C} \mathrm{min}^{-1}$.

\section{Deposition of the Cathode Layer}

The cathode was applied in two layers with the aid of a paint brush (Flat Artist Brushes, Toolzone, UK) onto the outer surface of the sintered electrolyte, thereby generating an electrode with two sub-structures. The first layer, adjacent to the electrolyte, was applied from a paste comprising $50 \mathrm{wt} . \% \mathrm{LSM}\left(\left(\mathrm{La}_{0.80} \mathrm{Sr}_{0.20}\right) \mathrm{MnO}_{3-\mathrm{x}}\right)$ and 50 wt.\% YSZ $\left(\left(\mathrm{Y}_{2} \mathrm{O}_{3}\right)_{0.08}\left(\mathrm{ZrO}_{2}\right)_{0.92}\right)$ with the solid content constituting $60-70 \%$ of the mass (Fuelcellmaterials, USA). Before the application of the second sub-layer, the fiber was dried in an oven (Elite Thermal Systems Ltd., UK) at $60{ }^{\circ} \mathrm{C}$ for 5 minutes. The second layer was then applied from a slurry of pure LSM powder $(\geq 99 \%$, Sigma Aldrich, UK) in ethylene glycol. After all the cathode layers were deposited, the fuel cell precursors were sintered at $1200{ }^{\circ} \mathrm{C}$ for 3 hours in air.

\section{Experimental Testing}

Structural Analysis of Fuel Cell Layers. Scanning electron microscopy was used to image cross-sectional dimensions and microstructures of the fuel cell layers. The Leo Gemini 1525 field emission gun scanning electron microscope (source FEGSEM, high resolution) was operated at $8-10 \mathrm{kV}$ at a working distance of 8-9 $\mathrm{mm}$ from the sample for backscattered electron (BSE detector) imaging or at $5 \mathrm{kV}$ and a working distance of 5-6 mm for in-lens secondary electron (SE detector) imaging.

Gas permeability measurements were made to check the electrolyte for micro-cracks; a length of sealed-off fiber was encased in a $300 \mathrm{~cm}^{3}$ volume capacity cylindrical stainless steel sample holder with the aid of epoxy resin and hardener (UKR-135 and UKH-136, respectively, UK Epoxy Resins, UK) (14). Nitrogen was introduced into the sample holder at a range of pressures; the change in pressure within the sample holder, an indication of finite gas permeance through the electrolyte, was measured as a function of time by a pressure gauge and the gas permeance was computed according to the formula in (14).

Current Collection and Sealing. Silver wires of $0.2 \mathrm{~mm}$ diameter (99.9\% purity, Sigma-Aldrich, UK ) were wrapped around the cathode length and fixed with platinum paste (SPI Supplies Platinum Paint, USA), which was used to decrease ohmic potential losses from the wires to the cathode surfaces. In addition, silver wires of $0.25 \mathrm{~mm}$ diameter $(99,9 \%$ purity, Sigma-Aldrich, UK) were formed into springs which were inserted inside the lumina of the fibers to enable current collection from the anodes.

Ceramic gas feed tubes (Multilab Ceramics, UK) were attached to the fibers using ceramic cement (Aremco, USA), which became gas-tight during two-hour sintering at $200{ }^{\circ} \mathrm{C}$ in air the silver wire current collectors protruded from the gas stream lines. 
Fuel Cell Performance Tests. The fuel cells were tested individually in a single cell quartz tube reactor (The Technical Glass Co., UK) with an outer diameter of $30 \mathrm{~mm}$ and a total length of $430 \mathrm{~mm}$. For testing, the reactor was sealed while leaving the ceramic gas channels and silver wire current collectors, connected to the fuel cell, to protrude outside.

The gases were introduced and collected from the ceramic channels and flowed along the length of the reactor at fixed rates: air was supplied to the cathode at $30 \mathrm{~cm}^{3} \mathrm{~min}^{-1}$ and the hydrogen fuel $\left(97 \% \mathrm{H}_{2}-3 \% \mathrm{H}_{2} \mathrm{O}\right)$ to the anode at $15 \mathrm{~cm}^{3} \mathrm{~min}^{-1}$. Each flow rate was controlled with a software-automated mass flow controller (Bronkhorst, UK)

The silver wire current collectors were connected to a potentiostat/galvanostat (Autolab PGSTAT 30, Eco Chemie, Netherlands) coupled with a booster (Autolab BSTR $10 \mathrm{~A}$, Eco Chemie, Netherlands). Electrochemical test procedures for measuring the voltage-current performances were applied using the Nova 1.5 software (Autolab, Eco Chemie, Netherlands).

A thermocouple (K-type Thermocouple, YC-747D-4 Channel Data Logger, Yu Ching Technology Ltd., Taiwan) was used for measuring the temperature inside the reactor.

Two electrochemical test procedures were applied to each fuel cell: A cyclic current scan procedure was applied to measure the cell voltage response of the fuel cell to applied current, corresponding to a current density range of $0-1 \mathrm{~A} \mathrm{~cm}^{-2}$, at three temperatures: 700, 750 and $800{ }^{\circ} \mathrm{C}$. Electrochemical impedance spectroscopy (EIS) measurements were used to characterize intrinsic electrical properties of the fuel cell materials and interfaces. EIS was controlled by FRA 4.9 module in the potentiostat/galvanostat (Frequency Response Analyzer, Autolab, Eco Chemie, Netherlands). Measurements were made at open circuit voltage (OCV) in the frequency range of $0.1 \mathrm{MHz}-10 \mathrm{mHz}$ at 700,750 and $800{ }^{\circ} \mathrm{C}$ using an ac voltage of $10 \mathrm{mV}$ (rms).

\section{Results and Discussion}

\section{Deposition of YSZ onto Pre-Reduced Fibers}

Figure 2 and Figure 3 show photographic images of the YSZ-coated Ni-YSZ fibers prior to and post sintering in air, respectively. Figure 3 clearly demonstrates the development of multiple cracks in the YSZ electrolyte during sintering, thus illustrating that electrophoretic deposition of electrolyte onto pre-reduced fibers is not an adequate procedure. It is proposed that the volume expansion of the fiber, due to the re-oxidation of $\mathrm{Ni}$ to $\mathrm{NiO}$ during sintering, was the primary reason for the development of cracks in the overlying electrolyte. It should be noted that sintering was performed in air rather than in $\mathrm{H}_{2}$, because the YSZ layer was expected to bond better with an oxide substrate.

\section{$\underline{\text { Step-by-Step Deposition of YSZ onto Non-Reduced Fibers }}$}

The principle behind this strategy was to overcome the problem of the volume expansion encountered with Ni-YSZ fibers during sintering. Figure 4 shows images of the YSZ electrolyte coating during the step-by-step deposition-sintering process. In spite 


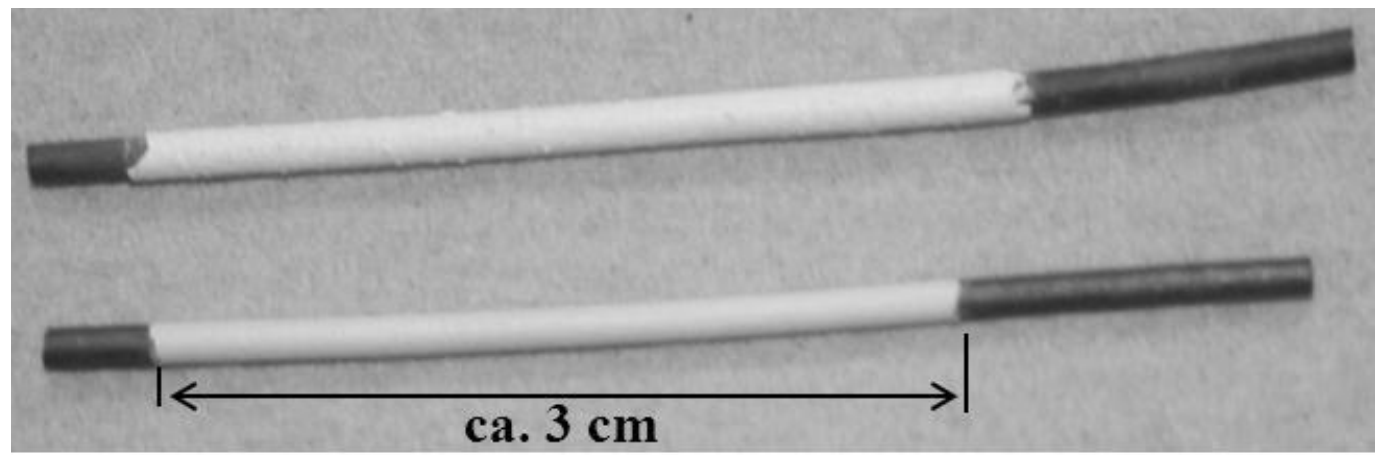

Figure 2: YSZ deposit on a pre-reduced NiO-YSZ hollow fibre anode before sintering.

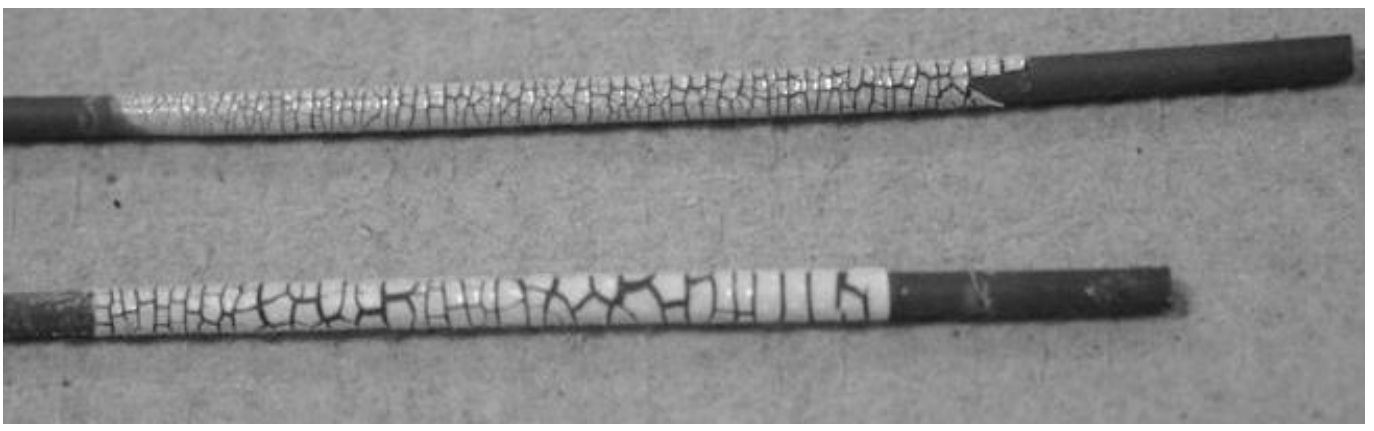

Figure 3: YSZ layer on a re-oxidised Ni-YSZ hollow fibre anode after sintering in air.

of the initial formation of cracks, the images reveal the gradual formation of a solid, crack-free surface as the number of coatings is increased. However, the gas permeance through the final, ca. $80 \mu \mathrm{m}$ thick, electrolyte layer was measured to be $2.23 \times 10^{-5} \mathrm{~mol} \mathrm{~m}^{-2} \mathrm{~s}^{-1} \mathrm{~Pa}^{-1}$, which is five orders of magnitude greater than the value of $10^{-10} \mathrm{~mol} \mathrm{~m}^{-2} \mathrm{~s}^{-1} \mathrm{~Pa}^{-1}$, at which the membrane is generally considered to be gas-tight (14). Hence, although an improvement on the previous result, the electrolyte layer in question was rendered unacceptable for use in fuel cells, due to the evident existence of microcracks. The failure of this method was predicated in the appearance of cracks in the early stages of the deposition process and diminished the value of sintering each layer at an ever increasing temperature. The deposition of further electrolyte layers to decrease the gas permeance was not attempted due to the already large thickness of the YSZ layer.

\section{One-Step Deposition of YSZ onto Non-Reduced Fibers}

The procedure that produced a successful result involved application of the YSZ electrolyte layer onto the NiO-YSZ hollow fiber in a single EPD step, followed by the cosintering of the two-layer system in a $\mathrm{H}_{2}$ atmosphere to form a YSZ/Ni-YSZ electrolyte/anode structure. The complete fuel cell, the cross-sectional images of which are shown in Figure 5, thus comprised a porous Ni-YSZ anode with a thickness of ca. 240 $\mu \mathrm{m}$, a non-porous YSZ electrolyte with a thickness of ca. $40 \mu \mathrm{m}$, and a porous LSM/LSM-YSZ cathode with a total thickness of ca. $35 \mu \mathrm{m}$. The fuel cell had an inner diameter of $1 \mathrm{~mm}$, an outer diameter of ca. $1.63 \mathrm{~mm}$ and an active length of ca. $35 \mathrm{~mm}$. The permeance of the electrolyte layer to nitrogen gas was determined to be ca. $8.2 \times 10^{-8}$ mol m${ }^{-2} \mathrm{~s}^{-1} \mathrm{~Pa}^{-1}$, which was a great improvement on the aforementioned results, although the value indicated that the electrolyte was still not fully gas-tight. 

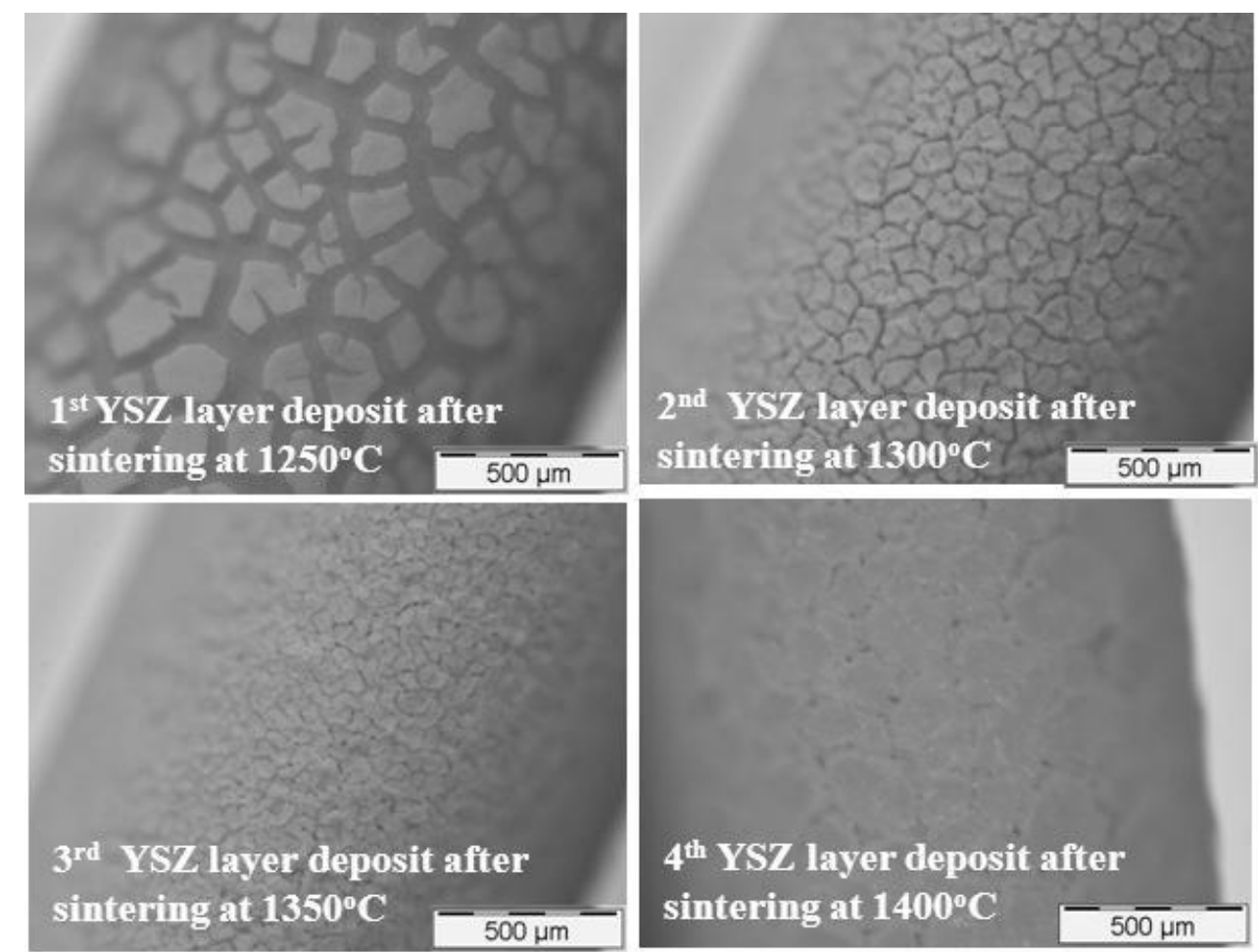

Figure 4: Optical microscope images of the YSZ electrolyte layers after each deposition-sintering step.

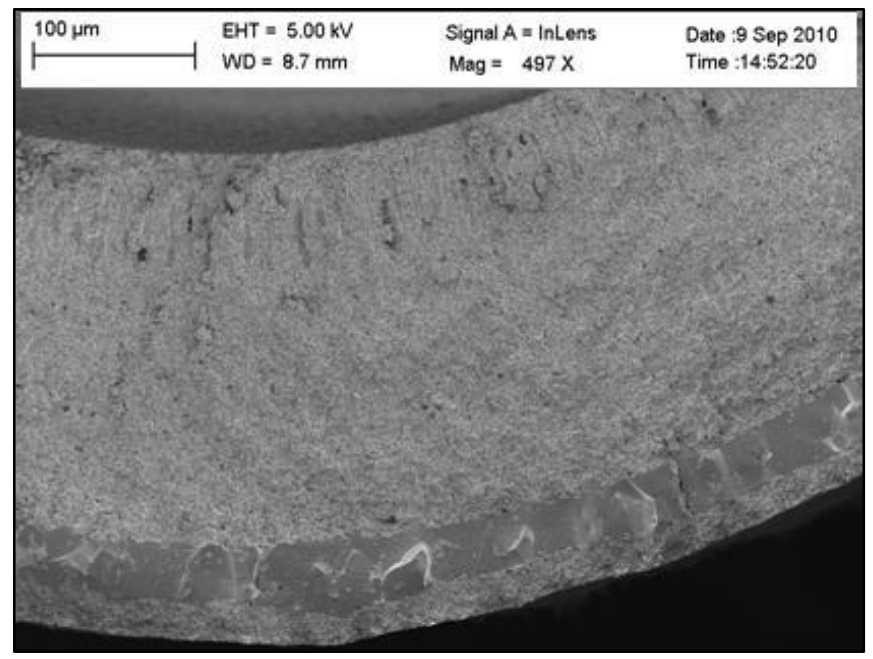

Figure 5: SEM image of the LSM/LSM-YSZ/YSZ/Ni-YSZ MT-SOFC cross- section

The HF-MT-SOFC delivered peak power densities of $0.20,0.18$ and $0.14 \mathrm{~W} \mathrm{~cm}^{-2}$ at $800{ }^{\circ} \mathrm{C}, 750{ }^{\circ} \mathrm{C}$ and $700{ }^{\circ} \mathrm{C}$, respectively; Figure 6 shows the power density outputs and cell voltage measurements as functions of current density. The results are compatible with those in (10), where EPD was employed in the fabrication of a tubular SOFC with a $10 \mu \mathrm{m}$ thick electrolyte, which generated $0.53 \mathrm{~W} \mathrm{~cm}^{-2}$ at $800{ }^{\circ} \mathrm{C}$. As the ohmic potential loss across the electrolyte of thickness $d$ and conductivity $\kappa$ is given by $\Delta \phi=j \cdot d / \kappa$, the performance of the MT-HF-SOFC, shown in Figure 5, could be improved easily by 
decreasing the thickness of the applied electrolyte layer to ca. $10 \mu \mathrm{m}$. By decreasing the electrolyte thickness from $40 \mu \mathrm{m}$ to $10 \mu \mathrm{m}$ the potential drop across the electrolyte, $\Delta \phi_{\text {electrolyte, }}$ at $800{ }^{\circ} \mathrm{C}$ could be decreased from $0.79 \mathrm{~V}$ to $0.20 \mathrm{~V}$ in the absence of gas leakage, based on the current density of $5.34 \times 10^{-1} \mathrm{~A} \mathrm{~cm}^{-2}$ at the peak power output and the YSZ conductivity of $2.69 \times 10^{-3} \mathrm{~S} \mathrm{~cm}^{-1}$ at $800{ }^{\circ} \mathrm{C}(15)$.

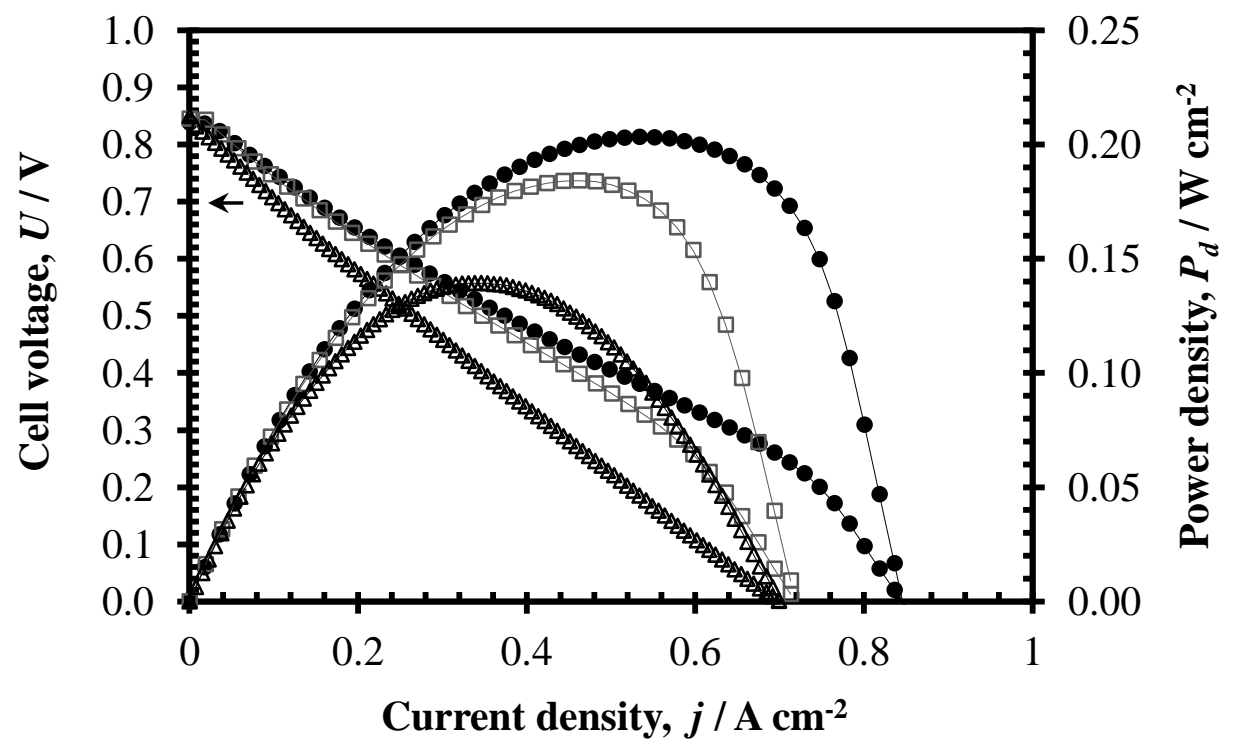

Figure 6: Effect of current density and temperature on cell voltages and power densities; measurements at $800{ }^{\circ} \mathrm{C}(\bullet), 750{ }^{\circ} \mathrm{C}(\square)$ and $700{ }^{\circ} \mathrm{C}(\Delta)$.

The performance of the MT-HF-SOFC is quantified in Table 1. The (high) area specific resistance (ASR) values were obtained from the high frequency intercepts of the Nyquist impedance plots with the real impedance axis. These values were attributed primarily to the thickness of the electrolyte, which needs to be decreased, and also to ohmic potential losses between the electrodes and their respective current collectors. The

Table 1: Peak power densities, ASR values and OCV data obtained for the MT-HF- SOFC

\begin{tabular}{|c|c|c|c|c|}
\hline $\begin{array}{c}\text { Temperature } \\
/{ }^{\circ} \mathrm{C}\end{array}$ & $\begin{array}{c}\text { Peak Power Density } \\
/ \mathrm{W} \mathbf{c m}^{-2}\end{array}$ & $\begin{array}{c}\text { Ohmic ASR } \\
/ \Omega \mathrm{cm}^{2}\end{array}$ & $\begin{array}{c}\text { OCV (measured) } \\
\text { / V }\end{array}$ & $\begin{array}{c}\text { OCV (theoretical) } \\
\text { / V }\end{array}$ \\
\hline 800 & 0.20 & 0.3 & 0.84 & 1.08 \\
\hline 750 & 0.18 & 0.5 & 0.85 & 1.09 \\
\hline 700 & 0.14 & 0.8 & 0.86 & 1.10 \\
\hline
\end{tabular}

deviation between the measured values and theoretical open circuit potential differences, computed using the Nernst equation, are attributed to gas leaks through the electrolyte layer, which was determined not to be fully gas tight. It is believed that this problem could also be obviated by decreasing the electrolyte thickness; co-sintering of a thinner electrolyte layer with the anode substrate has been reported to create a better quality electrolyte (16).

\section{Conclusions}

A successful new strategy for the fabrication of micro-tubular SOFCs has been reported, involving electrophoretic deposition of the YSZ electrolyte onto un-sintered, non- 
conductive NiO-YSZ hollow fiber anode precursors, followed by co-sintering in a $\mathrm{H}_{2}$ atmosphere at $1500{ }^{\circ} \mathrm{C}$. The fuel cell delivered a competitive peak power density of $0.20 \mathrm{~W} \mathrm{~cm}^{-2}$ at $800{ }^{\circ} \mathrm{C}$; its performance was affected adversely by the electrolyte thickness, which at ca. $40 \mu \mathrm{m}$ gave rise to large ohmic losses and also suffered from micro-crack development during experiments. Performance can be improved by decreasing the thickness of the electrolyte to $10 \mu \mathrm{m}$. Finally, it is probable that the process of electrophoretic deposition, which is known to be affected by the properties of the suspension as well as by deposition parameters, requires further testing and optimisation. A full investigation report will follow.

\section{Acknowledgments}

The authors thank the UK Engineering and Physical Research Council for providing a grant, supporting a studentship for N.D. The authors gratefully acknowledge Dr. Partho Sarkar (Alberta Research Council, Edmonton, Canada) for sharing his knowledge about EPD on tubular substrates and Mohd Hafiz Dzarfan Othman (now at: Universiti Teknologi Malaysia) for conducting the gas permeation tests.

\section{References}

1. N. Droushiotis, U. Doraswami, G.H. Kelsall and K. Li, J. Appl. Electrochem. 41, 1005 (2011).

2. M.H.D. Othman, N. Droushiotis, Z. Wu, G.H. Kelsall and K. Li, J. Power Sources, 196, 5035 (2011)

3. K. Kanawka, M.H.D. Othman, Z. Wu, N. Droushiotis, G.H. Kelsall and K. Li, Electrochem. Commun., 13, 93 (2011)

4. M.H.D. Othman, Z. Wu, N. Droushiotis, U. Doraswami, G.H. Kelsall and K. Li, J. Membr. Sci., 351, 196 (2010)

5. M.H.D. Othman, Z. Wu, N. Droushiotis, G.H. Kelsall and K. Li, J. Membr. Sci., 360, 410 (2010)

6. N. Droushiotis, U. Doraswami, D. Ivey, M.H.D. Othman, K. Li and G.H. Kelsall, Electrochem. Commun., 12, 792 (2010)

7. N. Droushiotis, U. Doraswami, K. Kanawka, G.H. Kelsall and K. Li, Solid State Ionics, 180, 1091 (2009)

8. N. Droushiotis, M.H.D. Othman, U. Doraswami, Z. Wu, G.H. Kelsall and K. Li, Electrochem. Commun., 11, 1799 (2009)

9. H. Negishi, N. Sakai, K. Yamaji, T. Horita and H. Yokokawa, J. Electrochem. Soc., 147, 1682 (2000)

10. P. Sarkar, L. Yamarte, H. Rho and L. Johanson, Int. J. Appl. Ceram. Technol., 4, 103 (2007)

11. I. Zhitomirsky and A. Petric, J. Eur. Ceram. Soc., 20, 2055 (2000)

12. P. Sarkar and P.S. Nicholson, J. Am. Ceram. Soc., 79, 1987 (1996)

13. H. Negishi, K. Yamaji, T. Imura, D. Kitamoto, T. Ikegami and H. Yanagishita, J. Electrochem. Soc., 152, J16, 2005

14. X. Tan, Y. Liu and K. Li, AIChE J., 51, 2005 (2005)

15. S.S. Liou and W.L. Worrell, Appl. Phys. A., 49, 25 (1989)

16. K. Kobayashi, I. Takahashi, M. Shiono and M. Dokiya, Solid State Ionics, 152-153, $591(2002)$ 